\title{
Costs of integrated plant protection in large-scale farms in 2006-2012
}

\section{Koszty integrowanej ochrony roślin \\ w gospodarstwach wielkoobszarowych w latach 2006-2012}

\author{
Maria Golinowska, Michał Kruszyński, Marcin Bogacz
}

\section{Summary}

The aim of the research was to analyse the costs of the integrated plant protection during the six year period in wheat, sugar beet and oilseed rape crops. The data analysed was collected from a large-scale farm located in wielkopolskie voivodeship. The simplified system of cultivation (zero-tillage) as well as the rules for the integrated production have been applied by the farm for 15 years. The following elements were subject of the analysis: expenditure on plant protection, the use of active substance of plant protection products per 1 ha of crops, calculated in weight units and monetary units and the costs of plan protection.

Key words: costs of integrated plant protection, winter wheat, rape, sugar beets, expenditure on plant protection, zero-tillage cultivation

\section{Streszczenie \\ W gospodarstwie wielkoobszarowym położonym w województwie wielkopolskim wykonano badania, których celem było przeprowadzenie sześcioletniej analizy kosztów integrowanej ochrony roślin w uprawach: pszenicy ozimej, buraków cukrowych i rzepaku. Analizowane gospodarstwo od ponad 15 lat stosuje technologię uprawy bezpłużnej i zachowuje zasady integrowanej produkcji. Analiza dotyczyła będzie określenia nakładów na ochronę roślin, takich jak: krotność zabiegów, zużycie substancji czynnej środków ochrony roślin na 1 ha uprawy w jednostkach wagowych, jak i monetarnych oraz koszty ochrony roślin.}

Słowa kluczowe: koszty integrowanej ochrony, pszenica ozima, rzepak, buraki cukrowe, nakłady na ochronę roślin, uprawa bezpłużna

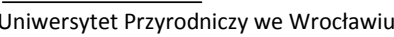

Zakład Ekonomiki Rolnictwa, Ochrony Roślin i Środowiska

PI. Grunwaldzki 24A, 50-363 Wrocław

maria.golinowska@up.wroc.pl; michal.kruszynski@up.wroc.pl 


\section{Wstęp / Introduction}

Integrowana produkcja (IP) jest systemem gospodarowania, w którym prowadzi się produkcję roślin z wykorzystaniem zrównoważonego postępu technicznego i biologicznego w uprawie, ochronie roślin i nawożeniu, zwracając szczególną uwagę na ochronę środowiska i zdrowie ludzi. Integrowana produkcja umożliwia uzyskanie płodów rolnych o najwyższej wartości biologicznej i odżywczej, bezpiecznej dla zdrowia człowieka. W Polsce IP została wprowadzona na podstawie przepisów Ustawy o ochronie roślin z 18 grudnia 2003 r. (Dz.U. z 2008 r. Nr 133, poz. $849 \mathrm{z}$ póź. $\mathrm{zm}$.) oraz rozporządzenia Ministra Rolnictwa i Rozwoju Wsi z 26 lipca 2004 r. w sprawie integrowanej produkcji (Dz.U. z 2004 r. Nr 178, poz. 1834 z późn. zm.). Nadzór oraz certyfikacja IP zostały powierzone Państwowej Inspekcji Ochrony Roślin i Nasiennictwa (Rolnictwo i gospodarka żywnościowa w Polsce 2010).

Prawidłowo prowadzona zgodnie z zasadami Dobrej Praktyki Ochrony Roślin uprawa wszystkich roślin jest podstawą do uzyskania wysokich plonów, dobrych jakościowo i bezpiecznych dla konsumentów. Podstawą do podjęcia decyzji w uprawach polowych o ochronie roślin powinno być oparcie jej o zasady integrowanej ochrony, czyli na koncepcji, która pojawiła się w ochronie roślin pod koniec lat 50. XX wieku (Stern i wsp. 1959), a od 1976 r. koncepcja ta została przyjęta jako oficjalny kierunek badań (Olszak i wsp. 2000).

Integrowana ochrona roślin jest celowym stosowaniem kombinacji metod biologicznych, biotechnologicznych, chemicznych, fizycznych, uprawowych i hodowlanych, przy których wykorzystanie chemicznych środków ochrony roślin ogranicza się do niezbędnego minimum i tylko w celu niedopuszczania do nadmiernego rozwoju organizmów szkodliwych, które mogłyby spowodować straty ekonomiczne.

Koncepcja integrowanej ochrony roślin (IPM) stała się podstawą do opracowania założeń i upowszechniania integrowanej produkcji (IP) roślin rolniczych i ogrodniczych (Boller i wsp. 2004; Pruszyński i wsp. 2004; Podleśny 2007). Zasady integrowanej ochrony roślin zawarte są w załączniku III Dyrektywy 2009/128/WE, a jest ich osiem (Golinowska 2012). Podstawą dobrego opracowania programu IPM jest zdobycie istotnych informacji, które zostaną wykorzystane w procesie decyzyjnym produkcji. Kolejność pozyskiwania informacji jest następująca:

1. identyfikacja agrofaga,

2. ocena populacji,

3. określenie uszkodzeń i strat (ujęcie ekonomiczne),

4. przegląd dostępnych metod ochrony roślin,

5. określenie możliwości interakcji agrofag - inne agrofagi - organizmy pożyteczne,

6. analiza lokalnych ograniczeń środowiskowych, społeczno-prawnych oraz ocena interakcji z innymi zabiegami,

7. podjęcie decyzji.

Koncepcja IPM stała się głównym kierunkiem działania Organizacji Rolnictwa i Wyżywienia FAO (Food and Agriculture Organization) oraz Światowej Organizacji Zdrowia WHO (World Health Organization). Integrowanie metod realizowane jest na różnych poziomach: agrofag pole - system produkcji. Najtrudniejszy do osiaggnięcia jest poziom trzeci (system produkcji), gdyż dotyczy on zależności: agrofag i jego zwalczanie, w różnych systemach uprawy.

Celem artykułu jest studium przypadku kształtowania się kosztów integrowanej ochrony roślin w gospodarstwie wielkoobszarowym stosującym system uprawy bezpłużnej.

\section{Materiały i metody / Materials and methods}

Do badań w sposób celowy wybrano gospodarstwo wielkoobszarowe, które od 15 lat stosuje system uprawy bezpłużnej wykorzystując zestaw Harsch TERRANO 5 FX o szerokości roboczej $10 \mathrm{~m}$. Materiały do badań pochodzą z zapisów księgowych oraz prowadzonych przez firmę kart historii pól, na których notuje się nakłady na poszczególne uprawy. Czasokres badań dotyczy lat 2006-2012 i obejmuje uprawy: pszenicy ozimej, rzepaku i buraka cukrowego. Zebrane materiały opracowano stosując następujące metody badawcze:

- analizę syntetyczną $1^{\circ}$ (Kopeć 1983),

- metodę kosztów jednostkowych,

- metodę określania nakładów na ochronę roślin (Golinowska 2002),

- metodę określania efektywności ekonomicznej zabiegów ochrony roślin (Mierzejewska i Golinowska 1976; Golinowska 2002),

- metody statystyczne.

Wyniki badań przedstawiono $\mathrm{w}$ formie tabelarycznej i na rysunkach.

\section{Wyniki i dyskusja / Results and discussion}

Badane gospodarstwo rolne położone jest w województwie wielkopolskim w powiecie Gostyń. Gospodarstwo to jest spółką z ograniczoną odpowiedzialnością. Powierzchnia gospodarstwa w roku 2007 i 2011 uległa zmniejszeniu (tab. 1). Osiągając w ostatnim roku 1518,6 ha. Wskaźnik waloryzacji rolniczej przestrzeni produkcyjnej dla rejonu, w którym znajduje się gospodarstwo według Witka (1993) wynosił 85,7 punktów, z czego 64,8 pkt., to jakość gleb, a pozostałe 20,9 pkt. za agroklimat. Gospodarstwo zatrudnia od 1,8 do 2 osób na 100 ha użytków rolnych (UR) (tab. 1). W latach 2006 i 2007 grunty własne przedsiębiorstwa stanowiły 15,8\% powierzchni gospodarstwa, a w latach 2008-2009 zmniejszył się udział gruntów dzierżawionych do $68,4 \%$ i w latach następnych grunty własne stanowiły 56,8\%. Struktura organizacji przedsiębiorstwa określona za pomocą systemu gospodarczego według Kopcia (1983), została przedstawiona w tabeli 1.

Przedsiębiorstwo w 2006 i 2007 r. posiadało nastawienie roślinne. W latach następnych zwiększano obsadę inwentarza żywego do 52 sztuk dużych SD/100 ha UR i wówczas nastawienie gospodarcze zostało zmienione na hodowlano-roślinne. Głównym kierunkiem produkcji roślinnej w latach 2006-2012 był rzepak i buraki cukrowe. W strukturze zasiewów zboża zajmowały od 44,4 do 
$56,9 \%$ gruntów ornych, rzepak stanowił od 25,3 do $38,2 \%$ i buraki cukrowe zajmowały około 10\%. Intensywność organizacji mierzona w punktach (Kopeć 1983) zwiększała się z 227,1 do 316,8 pkt. Badane przedsiębiorstwo zmieniło system gospodarczy $\mathrm{z}$ roślinno-rzepakowo-buraczanego $\mathrm{A}$, na system hodowlano-roślinny rzepakowo-buraczany $\mathrm{B}_{2}$.

$\mathrm{W}$ połowie lat dziewięćdziesiątych ubiegłego wieku w procesie produkcji roślinnej wprowadzono system uprawy bezpłużnej. Technologia tego systemu wymaga specjalnego sprzętu. I tak gospodarstwo używa do uprawy kultywator ścierniskowy typu HORSCH-TERRANO 5 FX. Jest to zestaw dwóch sprzężonych maszyn o szerokości roboczej $10 \mathrm{~m}$. Zestaw ten wykorzystywany jest $\mathrm{w}$ ciagu roku przez 715 godzin i wykonuje pracę na około 5000 ha. Wydajność pracy tego zestawu wynosi około $7 \mathrm{ha} / \mathrm{h}$. Gospodarstwo posiada również siewnik tej samej firmy. Do zabiegów ochrony roślin wykorzystywany jest specjalistyczny opryskiwacz typu TECNOMA LASER 5000. Jest to samojezdny opryskiwacz o szerokości roboczej $36 \mathrm{~m}$. Opryskiwacz ten w ciagu roku wykorzystywany jest przez 600 godzin, a powierzchnia, na której wykonywane są zabiegi ochrony roślin i nawożenia dolistnego w analizowanych latach wynosiła około 15 tys. ha. Wydajność pracy opryskiwacza wynosi średnio $25 \mathrm{ha} / \mathrm{h}$. Woda do opryskiwania pobierana jest $\mathrm{z}$ ujęcia $\mathrm{w}$ gospodarstwie.
Plony, jakie uzyskiwało gospodarstwo w latach 20062012 przedstawiono w tabeli 2.

Uzyskane plony były znacznie wyższe niż średnia dla Polski o ponad $50 \%$, a w niektórych przypadkach do $100 \%$ w zależności od uprawy. W latach 2006-2012 plony pszenicy ozimej, rzepaku i buraków cukrowych dorównywały wynikom uzyskiwanym w krajach Unii Europejskiej.

Ceny uzyskiwane ze sprzedaży ziemiopłodów w latach 2006-2012 były znacznie wyższe niż średnie ceny dla Polski, publikowane przez Główny Urząd Statystyczny (tab. 3), co świadczy o wysokiej jakości produktów i dużej oraz jednorodnej masie towarowej.

Gospodarstwo posiada swobodę w wyborze najkorzystniejszych transakcji sprzedaży płodów rolnych. Jakościowo dobry plon zapewnia odpowiednie zmianowanie, dokarmianie oraz ochrona roślin. Gospodarstwo dba o żyzność gleb stosując nawozy organiczne, takie jak: obornik i kurzeniec (Kucharski i Golinowska 2009). Obornik podawany jest pod buraki cukrowe w dawce $30 \mathrm{t} / \mathrm{ha} \mathrm{i}$ kurzeniec po $9 \mathrm{t} / \mathrm{ha}$ na pozostały areał uprawy buraków cukrowych oraz pod kukurydzę. Kurzeniec gospodarstwo stosuje pod rzepak w dawce $9 \mathrm{t} / \mathrm{ha}$ oraz pod pszenice ozima w tej samej dawce. W 2006 r. kurzeńcem nawieziono około 1400 ha, a obornikiem około 400 ha. Na 1000 ha gruntów stosowano wapnowanie. Taką technologię nawożenia organicznego gospodarstwo stosuje do

Tabela 1. Charakterystyka gospodarstwa

Table 1. Profile of the farms

\begin{tabular}{|c|c|c|c|c|c|c|}
\hline \multirow{2}{*}{$\begin{array}{l}\text { Wyszczególnienie } \\
\text { Specification }\end{array}$} & \multicolumn{6}{|c|}{ Lata - Years } \\
\hline & 2006 & 2007 & 2008 & 2009 & 2010 & 2011 \\
\hline $\begin{array}{l}\text { Powierzchnia gospodarstwa [ha] } \\
\text { Cropped area [ha] }\end{array}$ & 2573,4 & 2016,2 & 2016,02 & 2016,02 & 2015,8 & 1518,6 \\
\hline $\begin{array}{l}\text { Zatrudnienie [osób/100 ha UR] } \\
\text { Employment [people/100 ha UR] }\end{array}$ & 2,0 & 1,9 & 2,0 & 2,0 & 1,8 & 1,6 \\
\hline $\begin{array}{l}\text { Kierunek organizacji produkcji } \\
\text { roślinnej } \\
\text { Point of plant production organization }\end{array}$ & $\begin{array}{l}\text { rzepak } \\
\text { rape }\end{array}$ & $\begin{array}{l}\text { rzepak } \\
\text { rape }\end{array}$ & $\begin{array}{l}\text { rzepak } \\
\text { rape }\end{array}$ & $\begin{array}{l}\text { rzepak } \\
\text { rape }\end{array}$ & $\begin{array}{l}\text { rzepak } \\
\text { rape }\end{array}$ & $\begin{array}{l}\text { rzepak } \\
\text { rape }\end{array}$ \\
\hline $\begin{array}{l}\text { Nastawienie gospodarcze } \\
\text { Economic adjustment }\end{array}$ & $\mathrm{R}$ & $\mathrm{R}$ & $\mathrm{H}-\mathrm{R}$ & $\mathrm{H}-\mathrm{R}$ & $\mathrm{H}-\mathrm{R}$ & $\mathrm{H}-\mathrm{R}$ \\
\hline $\begin{array}{l}\text { Intensywność organizacji } \\
\text { Intensity of organization } \\
\end{array}$ & 249,1 & 227,1 & 316,7 & 299,0 & 315,0 & 316,8 \\
\hline $\begin{array}{l}\text { Zysk PLN na } 1 \text { ha UR } \\
\text { Arm income PLN per } 1 \text { ha } \\
\end{array}$ & 941,0 & 2477,4 & 422,1 & 1528,6 & 2587,8 & 4122,2 \\
\hline $\begin{array}{l}\text { Struktura zasiewów w \% } \\
\text { Croping structure in \% } \\
\text { - zboża - cereals } \\
\text { - rzepak - rape } \\
\text { - buraki cukrowe - sugar beets } \\
\text { - buraki pastewne - fodder beet }\end{array}$ & $\begin{array}{c}52,7 \\
25,3 \\
9,7 \\
11,1 \\
\end{array}$ & $\begin{array}{c}56,9 \\
28,6 \\
9,9 \\
4,6 \\
\end{array}$ & $\begin{array}{c}56,9 \\
28,6 \\
9,9 \\
4,6 \\
\end{array}$ & $\begin{array}{c}51,7 \\
26,9 \\
9,0 \\
12,4 \\
\end{array}$ & $\begin{array}{c}50,6 \\
32,0 \\
12,1 \\
5,3 \\
\end{array}$ & $\begin{array}{l}44,4 \\
38,2 \\
7,0 \\
6,9 \\
\end{array}$ \\
\hline $\begin{array}{l}\text { System gospodarczy } \\
\text { Farming system }\end{array}$ & $\begin{array}{c}\mathrm{R} \\
\text { rzepakowo- } \\
\text { buraczany } \\
\mathrm{A} \\
\mathrm{R} \\
\text { rape-beet } \\
\text { A }\end{array}$ & $\begin{array}{c}\mathrm{R} \\
\text { rzepakowo- } \\
\text { buraczany } \\
\mathrm{A} \\
\mathrm{R} \\
\text { rape-beet } \\
\text { A }\end{array}$ & $\begin{array}{c}\text { H-R } \\
\text { rzepakowo- } \\
\text { buraczany } \\
\text { B2 } \\
\text { R } \\
\text { rape-beet } \\
\text { A }\end{array}$ & $\begin{array}{c}\mathrm{H}-\mathrm{R} \\
\text { rzepakowo- } \\
\text { buraczany } \\
\text { B1 } \\
\text { R } \\
\text { rape-beet } \\
\text { A }\end{array}$ & $\begin{array}{c}\mathrm{H}-\mathrm{R} \\
\text { rzepakowo- } \\
\text { buraczany } \\
\mathrm{B} 2 \\
\mathrm{R} \\
\text { rape-beet } \\
\text { A }\end{array}$ & $\begin{array}{c}\mathrm{H}-\mathrm{R} \\
\text { rzepakowo- } \\
\text { buraczany } \\
\mathrm{B} 2 \\
\mathrm{R} \\
\text { rape-beet } \\
\mathrm{A}\end{array}$ \\
\hline
\end{tabular}

R - System Rolniczy - Agricultural System

H-R - System Hodowlano-Roślinny - Animality-Plant System

Źródło: opracowanie własne - Source: according to own research 
Tabela 2. Plony ziemiopłodów [dt/ha] i wydajność mleczna [1/1 krowę]

Table 2. Yields of crops [dt/ha] and milk yield [1/1 cow]

\begin{tabular}{l|c|c|c|c|c|c|c}
\hline \multirow{2}{*}{ Wyszczególnienie - Specification } & \multicolumn{7}{c}{ Lata - Years } \\
\cline { 2 - 9 } & 2006 & 2007 & 2008 & 2009 & 2010 & 2011 & 2012 \\
\hline Pszenica ozima - Winter wheat & 42 & 54 & 57 & 75 & 73 & 48 & 53 \\
\hline Jęczmień ozimy - Spring barley & - & 69 & - & - & - & - & - \\
\hline Kukurydza na ziarno - Maize & 80 & 130 & 80 & 120 & 93 & 111 & 120 \\
\hline Groch - Pea & 33 & - & - & - & - & 22 & 30 \\
\hline Rzepak - Rape & 35 & 34 & 34 & 36 & 31 & 29 & 26 \\
\hline Buraki cukrowe - Sugar beet & 600 & 740 & 530 & 730 & 485 & 650 & 960 \\
\hline $\begin{array}{l}\text { Kukurydza na zielonkę } \\
\text { Green maize }\end{array}$ & - & - & - & - & - & 520 & - \\
\hline $\begin{array}{l}\text { Mleko od 1 krowy } \\
\text { Milking yield per 1 dairy cow }\end{array}$ & 7690 & 8258 & 8620 & 8706 & 8949 & 9450 & 9560 \\
\hline
\end{tabular}

Źródło: opracowanie własne - Source: according to own research

Tabela 3. Ceny sprzedaży ziemiopłodów [PLN/dt]

Table 3. Salles prices of agricultural products $[\mathrm{PLN} / \mathrm{dt}]$

\begin{tabular}{c|c|c|c|c|c|c}
\hline \multirow{2}{*}{$\begin{array}{c}\text { Rok } \\
\text { Year }\end{array}$} & \multicolumn{2}{|c|}{ Pszenica ozima - Winter wheat } & \multicolumn{2}{c|}{ Rzepak - Rape } & \multicolumn{2}{c}{ Buraki cukrowe - Sugar beets } \\
\cline { 2 - 7 } & $\begin{array}{c}\text { gospodarstwo } \\
\text { farm }\end{array}$ & $\begin{array}{c}\text { Polska } \\
\text { Poland }\end{array}$ & $\begin{array}{c}\text { gospodarstwo } \\
\text { farm }\end{array}$ & $\begin{array}{c}\text { Polska } \\
\text { Poland }\end{array}$ & $\begin{array}{c}\text { gospodarstwo } \\
\text { farm }\end{array}$ & $\begin{array}{c}\text { Polska } \\
\text { Poland }\end{array}$ \\
\hline 2006 & 55,00 & 44,40 & 102,00 & 93,40 & 8,81 & 12,88 \\
\hline 2007 & 81,00 & 68,90 & 125,00 & 86,60 & 11,02 & 10,83 \\
\hline 2008 & 50,00 & 69,90 & 114,00 & 95,70 & 22,45 & 10,37 \\
\hline 2009 & 42,16 & 48,26 & 124,80 & 108,24 & 9,09 & 11,57 \\
\hline 2009 & 73,56 & 59,84 & 134,37 & 127,76 & 14,81 & 11,31 \\
\hline 2011 & 113,27 & 82,21 & 96,46 & 183,91 & 18,0 & 17,40 \\
\hline
\end{tabular}

Źródło: opracowanie własne - Source: according to own research

Tabela 4. Nakłady na chemiczną ochronę roślin

Table 4. The outlays on plant protection

\begin{tabular}{|c|c|c|c|}
\hline \multirow{2}{*}{ Wyszczególnienie - Specification } & \multicolumn{3}{|c|}{ Rok - Year } \\
\hline & 2006 & 2008 & 2012 \\
\hline $\begin{array}{l}\text { Zużycie ś.o.r. w kg s.cz./ha } \\
\text { Use of pesticides in kg of a.s. per ha } \\
\quad \text { - pszenica - winter wheat } \\
\text { - rzepak - rape } \\
\text { - buraki cukrowe - sugar beet }\end{array}$ & $\begin{array}{l}1,60 \\
1,80 \\
5,80\end{array}$ & $\begin{array}{l}1,45 \\
1,60 \\
5,59\end{array}$ & $\begin{array}{l}2,28 \\
2,46 \\
6,57\end{array}$ \\
\hline $\begin{array}{l}\text { Koszt zużycia środków [PLN/ha] } \\
\text { The costof the measures [PLN/ha] } \\
\text { - pszenica - winter wheat } \\
\text { - rzepak - rape } \\
\text { - buraki cukrowe - sugar beet }\end{array}$ & $\begin{array}{l}400 \\
380 \\
980\end{array}$ & $\begin{array}{c}360 \\
420 \\
1103\end{array}$ & $\begin{array}{l}350 \\
400 \\
930\end{array}$ \\
\hline $\begin{array}{l}\text { Krotność zabiegów } \\
\text { Mutipicity of treat ments } \\
\quad \text { - pszenica - winter wheat } \\
\quad \text { - rzepak - rape } \\
\quad \text { - buraki cukrowe - sugar beet }\end{array}$ & $\begin{array}{l}3 \\
5 \\
7\end{array}$ & $\begin{array}{l}4 \\
6 \\
6\end{array}$ & $\begin{array}{c}6 \\
10 \\
7\end{array}$ \\
\hline $\begin{array}{l}\text { Zużycie ś.o.r. PLN/ha } \\
\text { Use of pesticides in PLN/ha } \\
\text { - pszenica - winter wheat } \\
\text { - rzepak- rape } \\
\text { - buraki cukrowe- sugar beet }\end{array}$ & $\begin{array}{c}520 \\
600 \\
1220\end{array}$ & $\begin{array}{c}480 \\
520 \\
1253\end{array}$ & $\begin{array}{c}410 \\
500 \\
1000\end{array}$ \\
\hline
\end{tabular}

Źródło: opracowanie własne - Source: according to own research 
Tabela 5. Opłacalność ochrony roślin w latach 2006-2012

Table 5. Profitability of plant protection in 2006-2012

\begin{tabular}{|c|c|c|c|c|c|c|}
\hline \multirow{3}{*}{$\begin{array}{l}\text { Wyszczególnienie } \\
\text { Specification }\end{array}$} & \multicolumn{6}{|c|}{ Wskaźnik opłacalności - Profitability index } \\
\hline & 2006 & 2008 & 2012 & 2006 & 2008 & 2012 \\
\hline & \multicolumn{3}{|c|}{$\mathrm{E} 1=\frac{\mathrm{Kz}}{\mathrm{Ca}}[\mathrm{dt}]$} & \multicolumn{3}{|c|}{$\mathrm{E} 2=\frac{\mathrm{E} 1 \times 100}{\mathrm{p}}[\%]$} \\
\hline $\begin{array}{l}\text { Pszenica ozima } \\
\text { Winter wheat }\end{array}$ & 9,5 & 9,6 & 3,6 & 22,5 & 16,8 & 6,8 \\
\hline $\begin{array}{l}\text { Rzepak } \\
\text { Rape }\end{array}$ & 5,9 & 4,6 & 5,2 & 16,9 & 13,5 & 20,0 \\
\hline $\begin{array}{l}\text { Buraki cukrowe } \\
\text { Sugar beets }\end{array}$ & 138,5 & 55,8 & 55,8 & 27,0 & 10,5 & 6,2 \\
\hline
\end{tabular}

$\mathrm{Kz}$ - koszty faktyczne zabiegu ochronnego - actual costs of protection treatment [PLN/ha]

$\mathrm{Ca}$ - cena produktu chronionego - price of protected product $[\mathrm{PLN} / \mathrm{dt}]$

$\mathrm{p}-$ plon - yield [dt/ha]

Źródło: opracowanie własne - Source: according to own research

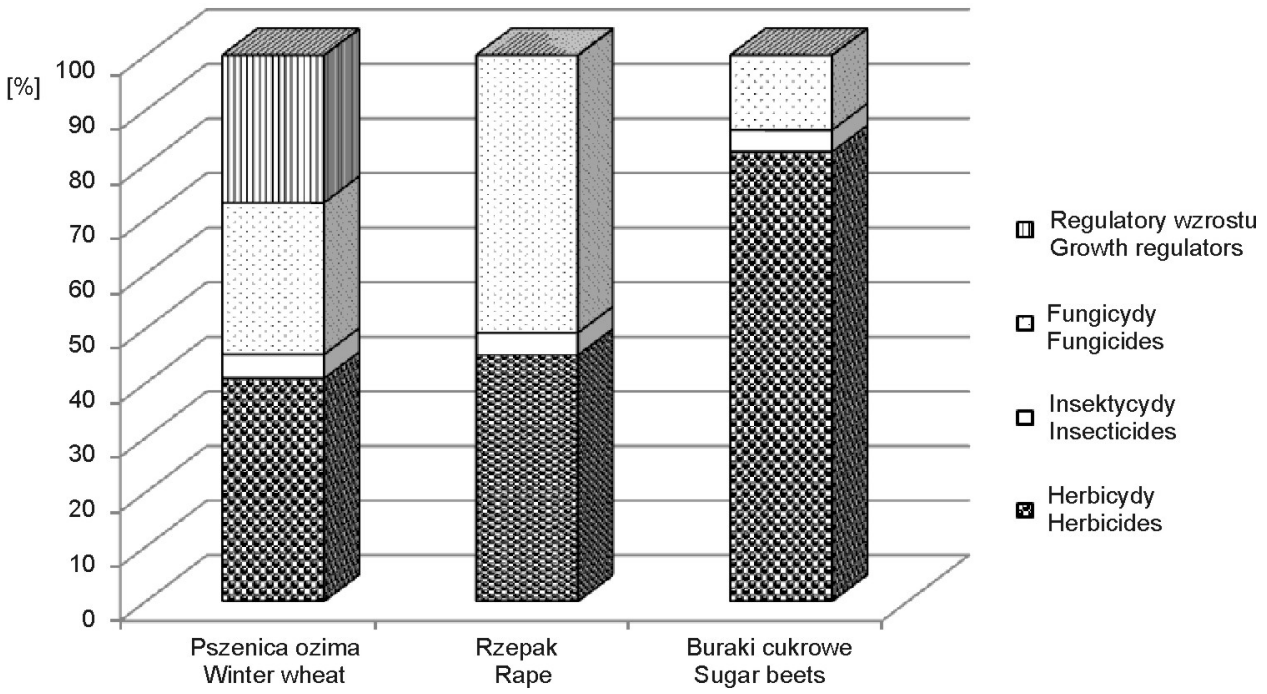

Rys. 1. Struktura zużycia środków ochrony roślin w kg substancji czynnej

Fig. 1. Structure of the use of plant protection product in $\mathrm{kg}$ of active substance

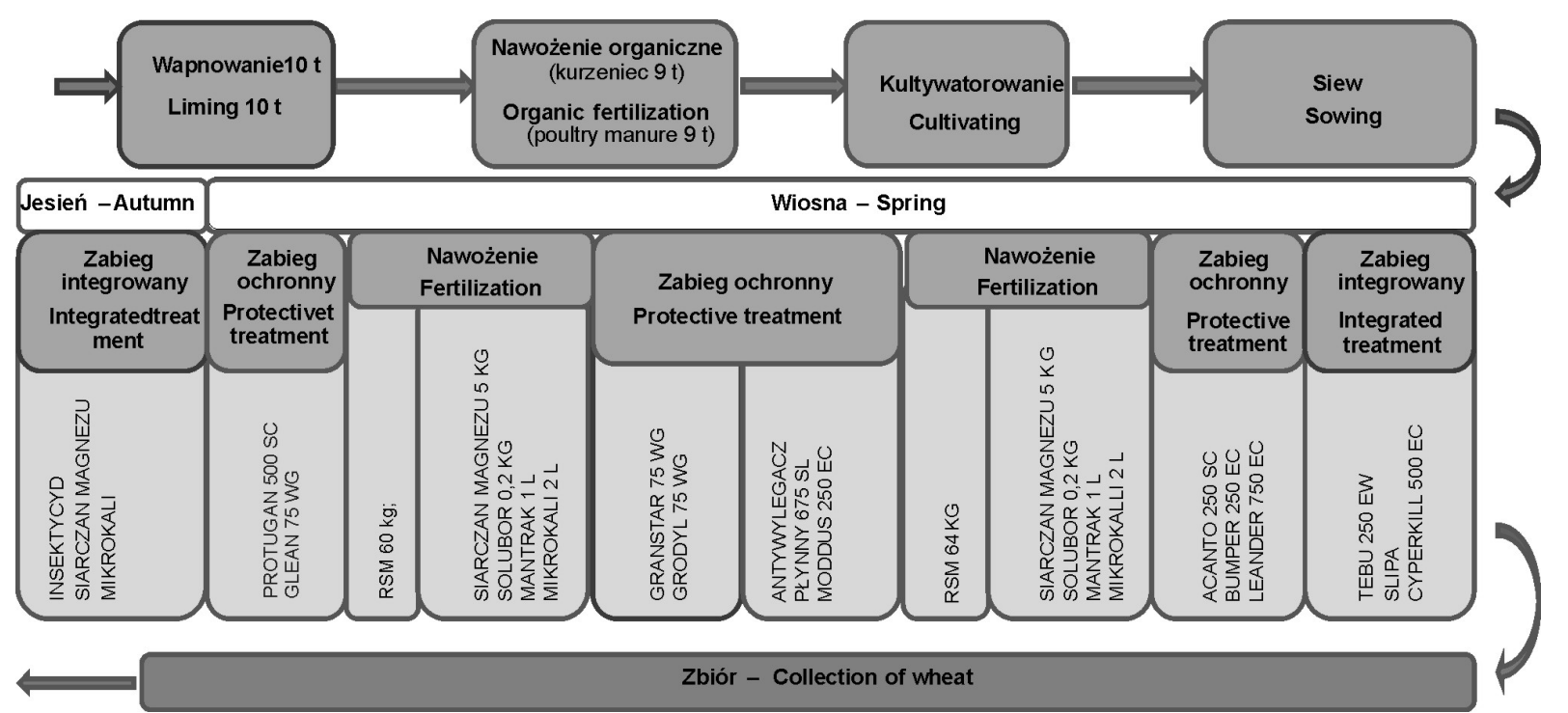

Rys. 2. Technologia uprawy pszenicy i zastosowane środki produkcji

Fig. 2. Technology of wheat production and measures 


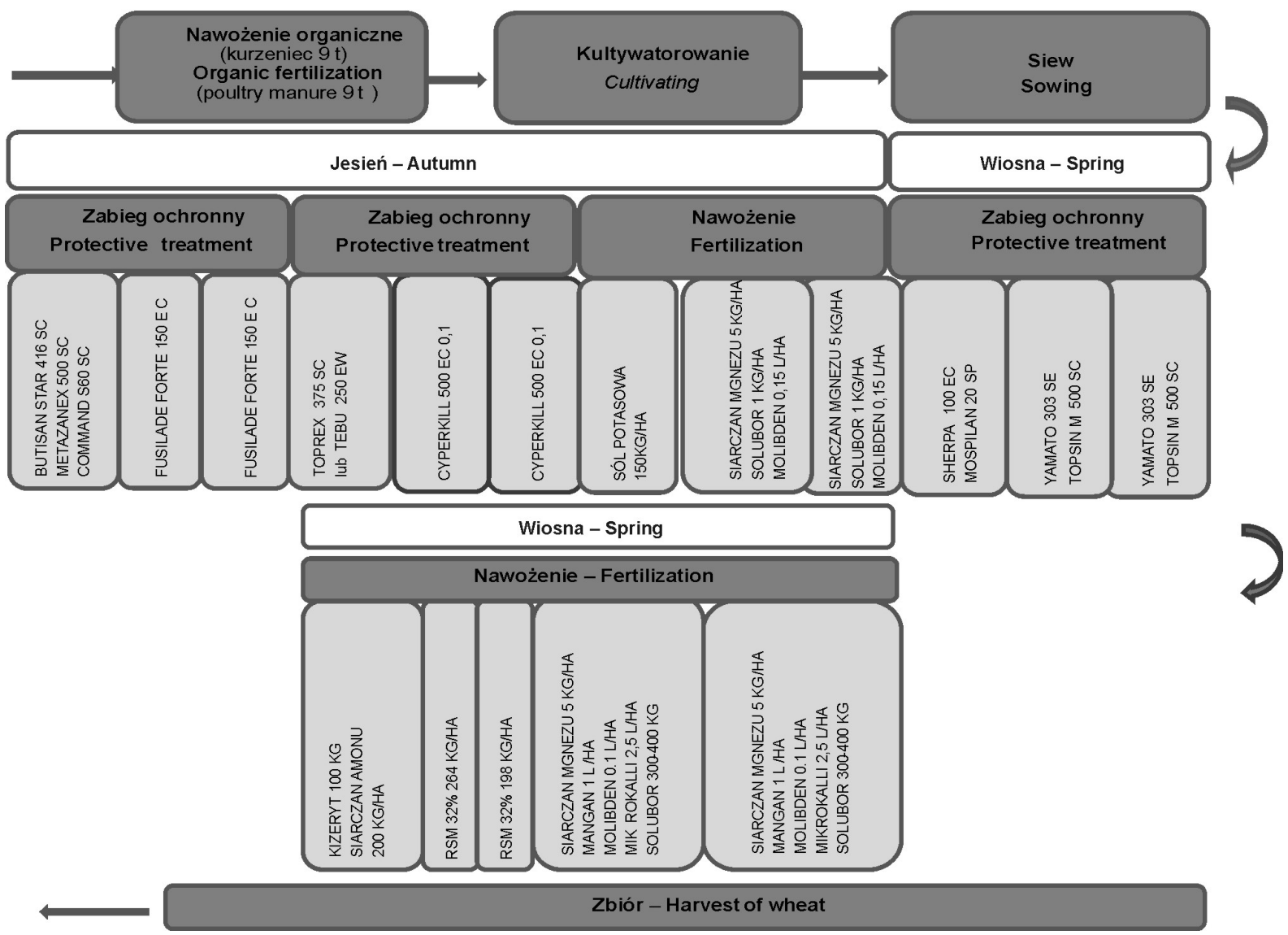

Rys. 3. Technologia uprawy rzepaku i zastosowane środki produkcji

Fig. 3. Technology applied to oil seed rape and the means of production

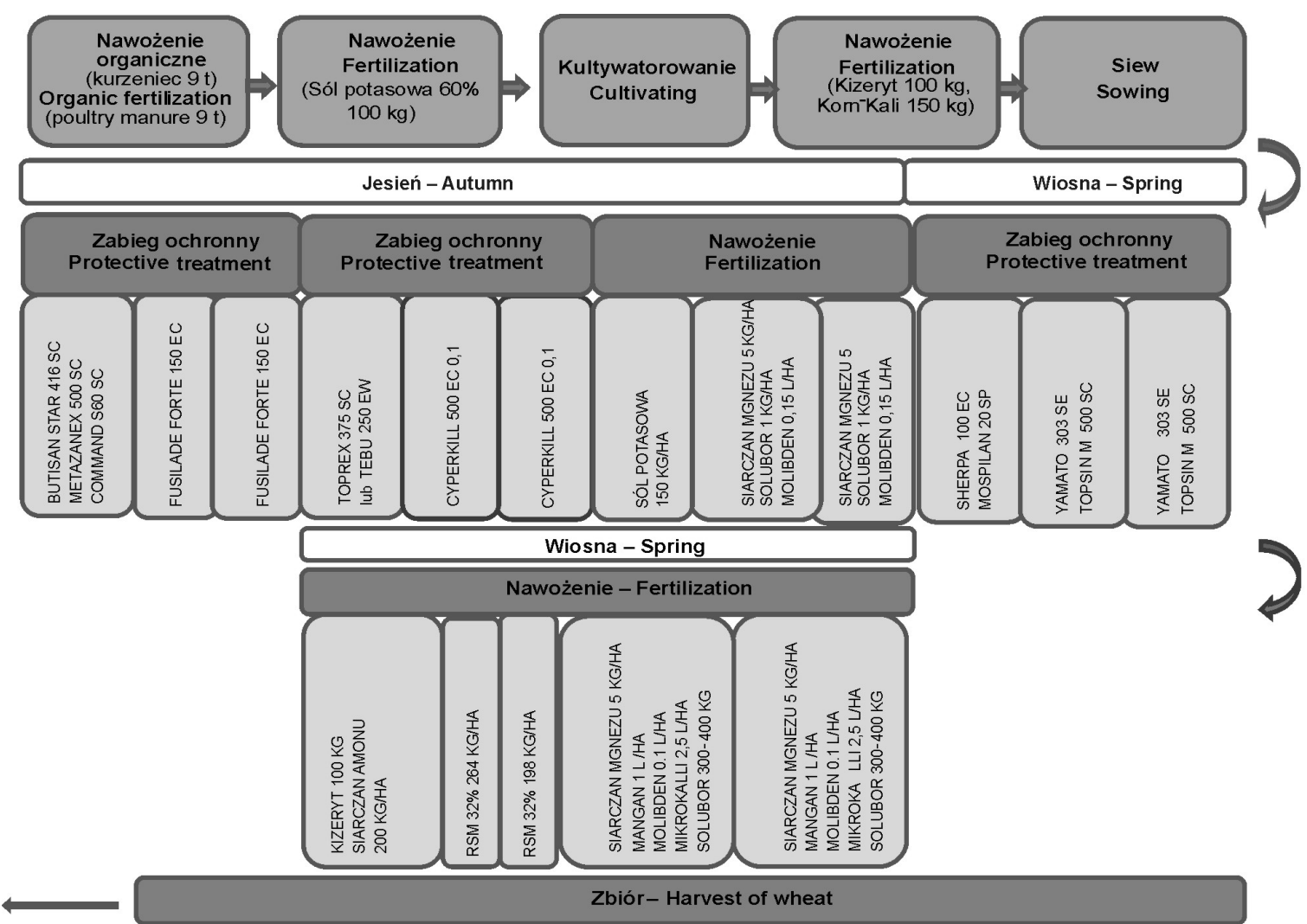

Rys. 4. Technologia uprawy buraków cukrowych i zastosowane środki produkcji

Fig. 4. Technology of sugar beet and used the means of production 
chwili obecnej. W kosztach operacyjnych przedsiębiorstwa zauważa się zmniejszenie udziału zakupu nawozów mineralnych z 23,5 do $8,8 \%$, a co za tym idzie zmniejsza się udział nawozów mineralnych na korzyść nawozów organicznych. Podkreślić należy fakt, że corocznie stosuje się wapnowanie gleby na powierzchni około 1000 ha przeznaczonej w głównej mierze pod pszenicę ozima. Zabieg ten realizowany jest $\mathrm{w}$ oparciu o badania kwasowości gleb. Zmniejszanie nawożenia mineralnego, kosztem zwiększania nawożenia organicznego jest jednym $\mathrm{z}$ elementów IP (integrowanej produkcji). Analizowane gospodarstwo $\mathrm{w}$ procesie produkcji roślinnej zachowuje zasady prawidłowego zmianowania.

W tabeli 4. przedstawiono nakłady na chemiczną ochronę roślin w latach: 2006, 2008 i 2012. Zużycie środków ochrony roślin (ś.o.r) w kg substancji czynnej na 1 ha, w analizowanych latach wahało się od 1,45 do $2,28 \mathrm{~kg} / \mathrm{ha}$ w uprawie pszenicy ozimej. Koszt ś.o.r. na 1 ha w zależności od uprawy i roku wahał się od 350 do 1103 PLN/ha.

W strukturze zużycia pestycydów $\mathrm{w}$ analizowanych uprawach dominują herbicydy, których udział wahał się od 40,8 do $82,3 \%$ (rys. 1). W uprawie rzepaku fungicydy zajmują ponad $50 \%$, a zużycie insektycydów w badanych uprawach wynosiło około $4 \%$. W ostatnich latach, w uprawie buraka cukrowego znaczenia gospodarczego nabiera zwalczanie chorób grzybowych. Krotność zabiegów ochrony roślin $\mathrm{w}$ pszenicy ozimej i rzepaku wzrosła dwukrotnie w porównaniu do 2006 r., a w uprawie buraka cukrowego wynosi 7 (tab. 4). Pomimo wzrostu zużycia substancji czynnej i krotności zabiegów koszty faktyczne chemicznej ochrony roślin na 1 ha analizowanych upraw wykazują w badanym gospodarstwie tendencję malejąca. $\mathrm{Na}$ wysokość kształtowania tych kosztów mają wpływ ceny ś.o.r oraz wysoka sprawność opryskiwacza.

Opłacalność zabiegów ochrony roślin określona za pomocą orientacyjnych wskaźników opłacalności przedstawiona została w tabeli 5 .

Najkorzystniejszą opłacalnością chemicznej ochrony roślin w latach 2006-2012 charakteryzowała się uprawa buraków cukrowych, a najgorszą rzepak. Stosując się do zasad IP i IPM badane gospodarstwo poprawia efektywność ekonomiczną gospodarowania, która wyraża się uzyskiwaniem wysokich plonów. W procesie technologicznym analizowanych upraw zauważa się integrowanie zabiegów ochronnych w pszenicy, gdzie łączy się zabiegi insektycydowe $\mathrm{z}$ fungicydowymi, a $\mathrm{w}$ nawożeniu dolistnym w każdej uprawie wykonuje się oprysk składający się z kilku elementów.

Proces technologiczny integrowanej produkcji w pszenicy składał się z 13 elementów, w burakach cukrowych z 16 i w rzepaku z 20 (rys. 2, 3, 4). Zbyt duży udział rzepaku $\mathrm{w}$ strukturze zasiewów powoduje zachwianie równowagi $\mathrm{w}$ zmianowaniu, wzrasta krotność zabiegów, a uzyskiwany plon $\mathrm{w}$ gospodarstwie $\mathrm{w}$ miarę zwiększania się powierzchni uprawy rzepaku maleje (tab. 2). Pomimo wzrastających cen skupu rzepaku opłacalność chemicznej ochrony tej uprawy jest niska (tab. 5).

\section{Wnioski / Conclusions}

Przeprowadzone badania wykazały:

1. Gospodarstwo w analizowanym okresie zwiększało intensywność organizacji, czego wyrazem jest system gospodarczy H-R rzepakowo-buraczany B2.

2. W gospodarstwie przestrzega się zasady IP (integrowanej produkcji), takie jak: obniżanie zużycia $\mathrm{w}$ procesie produkcji roślinnej nawozów mineralnych, natomiast koszty środków ochrony roślin na 1 ha wykazuja tendencję malejącą pomimo zwiększającego się zużycia pestycydów w kg substancji czynnej i zwiększającej się krotności zabiegów.

3. W gospodarstwie dba się o żyzność gleby i odpowiednie $\mathrm{pH}$ stosując wapnowanie.

4. Opłacalność chemicznej ochrony roślin wyrażona wskaźnikami ekonomicznymi w miarę udoskonalania IP i IPM w latach 2006-2012 wzrosła w uprawie pszenicy ozimej i buraków cukrowych, a w rzepaku była niezadowalająca.

\section{Literatura / References}

Boller E., Avilla J., Joerg E., Malavolta F., Esbjerg P. 2004. Integrated Production. Principles and Technical Guidelines. 3rd ed. IOBC/WPRS Bull. 27 (2): 1-49.

Golinowska M. 2002. Efektywność ochrony roślin w indywidualnych gospodarstwach rolnych południowo-zachodniej Polski. Zesz. Nauk. AR Wrocław, 433, 199 ss.

Golinowska M. 2012. Koszty integrowanej ochrony roślin. [Costs of integrated plant protection]. Prog. Plant Prot./Post. Ochr. Roślin 52 (3): 521-526.

Kopeć B. 1983. Metodyka badań ekonomicznych w gospodarstwach rolnych (wybrane zagadnienia). Skrypt AR Wrocław 269,283 ss.

Kucharski K., Golinowska M. 2009. Efektywność ekonomiczna zabiegów ochrony roślin w systemie uprawy bezpłużnej. [Economic efficiency of plant protection treatments in non-ploughing system]. Prog. Plant Prot./Post. Ochr. Roślin 49 (2): $484-491$.

Mierzejewska W., Golinowska M. 1976. Koszty i ekonomiczna efektywność chemicznych zabiegów ochrony roślin. PWRiL, Warszawa, $55 \mathrm{ss}$

Olszak R., Pruszyński S., Lipa J.J., Dąbrowski Z.T. 2000. Rozwój koncepcji i strategii wykorzystania metod i środków ochrony roślin. [Development of the concepts and strategies of plant protection - methods and means]. Prog. Plant Prot./Post. Ochr. Roślin 40 (1): 40-50.

Podleśny J. (red.). 2007. Integrowana produkcja roślinna. Zagadnienia wybrane. IUNG, Puławy, 212 ss.

Pruszyński S., Zych A., Nawrot J. 2004. Prawne i praktyczne aspekty integrowanych technologii produkcji upraw rolnych w Polsce. [Legal and practical aspects of integrated management in agricultural crops in Poland]. Prog. Plant Prot./Post. Ochr. Roślin 44 (1): $300-305$.

Rolnictwo i gospodarka żywnościowa w Polsce. 2010. Ministerstwo Rolnictwa i Rozwoju Wsi, 76 ss.

Stern V., Smith R., Van den Bosch R., Hagen K. 1959. The integrated control concept. Hilgardis 29 (2): 81-101.

Witek T. (praca zbiorowa). 1993. Waloryzacja rolniczej przestrzeni produkcyjnej Polski według gmin. IUNG, Puławy, 245 ss. 